\title{
Whey protein isolate improves acid and bile tolerances of Streptococcus thermophilus ST-M5 and Lactobacillus delbrueckii ssp. bulgaricus LB-12
}

\author{
Luis A. Vargas, Douglas W. Olson, and Kayanush J. Aryana ${ }^{1}$ \\ School of Animal Sciences, Louisiana State University Agricultural Center, Baton Rouge 70803
}

\begin{abstract}
Acid tolerance and bile tolerance are important probiotic characteristics. Whey proteins contain branchedchain amino acids, which play a role in muscle building and are popular among athletes. Increasing emphasis is being placed on diets containing less carbohydrate, less fat, and more protein. The effect of incremental additions of whey protein isolate (WPI) on probiotic characteristics of pure cultures is not known. The objective of this study was to determine the influence of added WPI on acid tolerance and bile tolerance of pure cultures of Streptococcus thermophilus ST-M5 and Lactobacillus bulgaricus LB-12. The WPI was used at 0 (control), 1, 2 and $3 \%$ (wt/vol). Assessment of acid tolerance was conducted on pure cultures at 30-min intervals for $2 \mathrm{~h}$ of acid exposure and bile tolerance at 1-h intervals for $5 \mathrm{~h}$ of bile exposure. Use of 1, 2, and 3\% WPI improved acid tolerance of Strep. thermophilus ST-M5 and $L b$. bulgaricus LB-12. The highest counts for acid tolerance of Strep. thermophilus ST-M5 and Lb. bulgaricus LB-12 were obtained when $3 \%$ WPI was used. Use of 2 and $3 \%$ WPI improved bile tolerance of Strep. thermophilus ST-M5 and Lb. bulgaricus LB-12 over $5 \mathrm{~h}$ of bile exposure. The use of WPI is recommended to improve acid and bile tolerance of the yogurt culture bacteria Strep. thermophilus ST-M5 and Lb. bulgaricus LB-12.
\end{abstract}

Key words: probiotic, culture, whey protein isolate, yogurt

\section{INTRODUCTION}

Probiotics are a steadily growing market with global sales of probiotics having reached $\$ 21.6$ billion and $\$ 24.23$ billion in 2010 and 2011, respectively, with the market expected to reach $\$ 31.1$ billion and $\$ 44.9$ billion in 2015 and 2018, respectively (Pedretti, 2013). Growth of the probiotic market is due to increased awareness of the health benefits provided by probiotic bacteria. Before probiotics can confer health benefits to their

Received September 17, 2014

Accepted December 12, 2014.

${ }^{1}$ Corresponding author: karyana@agcenter.lsu.edu host, live cells must reach and establish in the lower gastrointestinal (GI) tract (Gerez et al., 2012) before which cells must survive the acidic conditions of the stomach and the bile in the GI tract. Therefore, acid tolerance and bile tolerance are important probiotic characteristics. Streptococcus thermophilus and Lactobacillus delbrueckii ssp. bulgaricus are yogurt culture bacteria that have health beneficial properties but that are affected, to some degree, by the acidic conditions of the stomach and the presence of bile in the GI tract.

Whey protein concentrate (WPC) and whey protein isolate (WPI) are used in food product manufacture and have been reported to have a beneficial influence on viability of probiotic and culture bacteria within the food product. Viability of Streptococcus thermophilus, Lb. delbrueckii ssp. bulgaricus and Bifidobacterium animalis in reduced-fat yogurt supplemented with $1.5 \%$ WPC was increased up to $1 \log \mathrm{cfu} / \mathrm{g}$ after $1 \mathrm{wk}$ of storage compared with yogurt with no with WPC (Akalin et al., 2007). When specific AA, such as cysteine, were added to yogurt, a significant increase in viability of culture and probiotic bacteria (Lb. delbrueckii ssp. bulgaricus, Lactobacillus acidophilus, Bifidobacterium bifidum BB12, and Lactobacillus paracasei) was found (Güler-Akin and Akin, 2007).

Addition of $0.5 \%$ WPC and other milk ingredients to replace nonfat dry milk resulted in an increase in counts of Strep. thermophilus, Lb. delbrueckii ssp. bulgaricus, and $B$. animalis after $14 \mathrm{~d}$ of storage at $4^{\circ} \mathrm{C}$ (Marafon et al., 2011). After $28 \mathrm{~d}$ of $4^{\circ} \mathrm{C}$ storage, counts of Strep. thermophilus and B. animalis were higher in yogurt supplemented with $0.5 \%$ WPC than counts in yogurt with added nonfat dry milk (Marafon et al., 2011). Dave and Shah (1998a) reported that after $5 \mathrm{wk}$ of $4^{\circ} \mathrm{C}$ storage, counts of Strep. thermophilus in yogurt supplemented with WPC and casein hydrolysate were up to $0.5 \log \mathrm{cfu} / \mathrm{mL}$ higher compared with yogurts with no supplementation. They further reported that bifidobacteria counts were $4 \log \mathrm{cfu} / \mathrm{mL}$ higher in yogurt supplemented with WPC than in yogurt with no WPC supplementation. Fortification of yogurt with up to $4 \%$ of whey protein hydrolysates improved the growth of $L b$. acidophilus by $3 \log$ cycles and enhanced the growth of Strep. thermophilus (Lucas et al., 2004). 
Whey proteins are the proteins of choice for athletes and body builders for muscle recovery after weight lifting and workout routines (Tipton et al., 2007). Whey proteins are sources of the branched-chain AA leucine, isoleucine, and valine, 3 essential AA (Sowers, 2009). Branched-chain AA enter the bloodstream through the liver and are oxidized in muscle tissue to provide energy during exercise (Garlick and Grant, 1988; Morifuji et al., 2009; Sowers, 2009).

Prevention of cancer and diabetes, weight loss, and reduction of appetite are linked to low-carbohydrate and high-protein diets (Weigle et al., 2005; Wycherley et al., 2010). Thus, diets containing less carbohydrate, less fat, and more protein are becoming more important (Weigle et al., 2005, Wycherley et al., 2010). Whey protein isolate contains more than $90 \%$ protein. Information on the influence of WPI on acid tolerance and bile tolerance is lacking. The objective was to study the effect of incremental addition of WPI on acid tolerance and bile tolerance of Strep. thermophilus and $L b$. delbrueckii ssp. bulgaricus.

\section{MATERIALS AND METHODS}

\section{Experimental Design}

The treatments consisted of WPI (Grände Ultra 9100; Grände Custom Ingredients Group, Milwaukee, WI) added at 0 (control), 1, 2, and $3 \%$ (wt/vol) to de Man, Rogosa, and Sharpe (MRS) broth for Lb. bulgaricus and to M17 broth for Strep. thermophilus. Acid tolerance of pure cultures (Strep. thermophilus ST-M5 and $L b$. bulgaricus LB-12) was evaluated every $30 \mathrm{~min}$ for $2 \mathrm{~h}$, and bile tolerance of pure cultures was determined every $1 \mathrm{~h}$ for $5 \mathrm{~h}$. The experiments were conducted and analyzed as a randomized block design with repeated measures. The 3 replications were the blocks.

\section{Preparation of Media}

The MRS broth for acid tolerance of Lb. bulgaricus was prepared by adding $55 \mathrm{~g}$ of MRS broth powder (Difco, Becton, Dickinson and Co., Sparks, MD) to 1 $\mathrm{L}$ of distilled water, and M17 broth for acid tolerance of Strep. thermophilus was prepared by adding $37.25 \mathrm{~g}$ of M17 broth powder (Oxoid, Basingstoke, UK) to 950 $\mathrm{mL}$ of distilled water. The MRS and M17 broths were adjusted to $\mathrm{pH} 2$ using $1 \mathrm{~N} \mathrm{HCl}$ and monitored with a calibrated $\mathrm{pH}$ meter (Extech Instruments, Waltham, MA). The MRS and M17 broths were sterilized at $121^{\circ} \mathrm{C}$ for $15 \mathrm{~min}$. A lactose solution $(10 \% \mathrm{wt} / \mathrm{vol})$ was sterilized and $50 \mathrm{~mL} / \mathrm{L}$ of lactose solution was aseptically added to previously sterilized M17 broth.
The MRS-THIO broth for bile tolerance of $L b$. bulgaricus was prepared by adding $55 \mathrm{~g}$ of MRS broth powder (Difco), $3 \mathrm{~g}$ of bovine bile (oxgall; US Biological, Swampscott, MA), and $2 \mathrm{~g}$ of sodium thioglycolate (Acros Organics, Fair Lawn, NJ) to 1 L of distilled water. Oxgall was added to test the bile tolerance of both bacteria; sodium thioglycolate was used as an oxygen scavenger for $L b$. bulgaricus in MRS broth. The final $\mathrm{pH}$ of the oxgall-supplemented MRS-THIO broth was $6.70 \pm 0.20$. This MRS-THIO broth was sterilized at $121^{\circ} \mathrm{C}$ for $15 \mathrm{~min}$.

The M17 broth for bile tolerance of Strep. thermophilus was prepared by adding $37.25 \mathrm{~g}$ of M17 broth powder (Oxoid) and $3 \mathrm{~g}$ of oxgall (US Biological) per $950 \mathrm{~mL}$ of distilled water. The final $\mathrm{pH}$ of the oxgall-supplemented M17 broth was $7.00 \pm 0.20$. This M17 broth was sterilized at $121^{\circ} \mathrm{C}$ for $15 \mathrm{~min}$. A lactose solution (10\% wt/ vol) was sterilized and $50 \mathrm{~mL}$ was aseptically added to previously sterilized M17 broth.

Lactobacilli MRS agar for pour plating was prepared according to manufacturer's directions and Tharmaraj and Shah (2003). Lactobacilli MRS agar (Difco) was suspended at a concentration of $70 \mathrm{~g} / \mathrm{L}$ of distilled water. The $\mathrm{pH}$ was adjusted to 5.2 with $1 \mathrm{~N} \mathrm{HCl}$. The medium was heated to boiling with agitation to completely dissolve the powder and was then sterilized at $121^{\circ} \mathrm{C}$ for $15 \mathrm{~min}$.

The M17 agar for pour plating was prepared according to the manufacturer's directions by adding 48.25 g of M17 agar powder (Oxoid) per $950 \mathrm{~mL}$ of distilled water with agitation and boiling gently. Then, the M17 agar was sterilized at $121^{\circ} \mathrm{C}$ for $15 \mathrm{~min}$. A lactose solution $(10 \% \mathrm{wt} / \mathrm{vol})$ was separately autoclaved at $121^{\circ} \mathrm{C}$ for $15 \mathrm{~min}$. This lactose solution was aseptically added at $50^{\circ} \mathrm{C}$ at a rate of $50 \mathrm{~mL}$ to $950 \mathrm{~mL}$ of previously sterilized M17 agar.

Peptone water $(0.1 \%)$ was prepared by dissolving 1 $\mathrm{g}$ of peptone powder (Bacto Peptone, Difco) per $1 \mathrm{~L}$ of distilled water. Peptone water $(99 \mathrm{~mL})$ was autoclaved in dilution bottles at $121^{\circ} \mathrm{C}$ for $15 \mathrm{~min}$.

\section{Acid Tolerance}

Acid tolerance was determined according to the method proposed by Pereira and Gibson (2002), with slight modifications. The M17 and MRS broths contained 0 (control), 1, 2, and 3\% (wt/vol) added WPI (Grände Custom Ingredients Group). After addition of WPI, the $\mathrm{pH}$ of both broths was adjusted to 2, using a sterilized magnetic stirrer bar for agitation. Freshly thawed pure cultures of Strep. thermophilus ST-M5 and Lb. bulgaricus LB-12 (Chr. Hansen, Milwaukee, WI) were used to separately inoculate M17 broth (pH 2) and MRS broth ( $\mathrm{pH} 2)$, respectively. Inoculated broths 
(pH 2) containing control and added WPI samples were incubated for $2 \mathrm{~h}$ at $43^{\circ} \mathrm{C}$ for $\mathrm{Lb}$. bulgaricus and $37^{\circ} \mathrm{C}$ for Strep. thermophilus.

Inoculated MRS and M17 broths were 10-fold serially diluted in $0.1 \%$ (wt/vol) peptone water and pour plated in duplicate every $30 \mathrm{~min}$ during the $2 \mathrm{~h}$ of incubation. Lactobacillus bulgaricus were enumerated by pour plating using previously prepared MRS agar ( $\mathrm{pH} 5.2)$ and anaerobically incubated at $43^{\circ} \mathrm{C}$ for $72 \mathrm{~h}$. Streptococcus thermophilus were enumerated by pour plating using previously prepared M17 agar and aerobically incubated at $37^{\circ} \mathrm{C}$ for $24 \mathrm{~h}$ (Dave and Shah, 1998a). After the incubation period, the colonies were counted.

\section{Bile Tolerance}

Bile tolerance was determined according to the method proposed by Pereira and Gibson (2002) with slight modifications. Both the MRS-THIO broth and the M17 broth contained $0.3 \%$ (wt/vol) oxgall. To both these broths, WPI (Grände Ultra 9100; Grände Custom Ingredients Group) was added at 0 (control), 1, 2 , and $3 \%$ (wt/vol). The MRS-THIO and M17 broths were inoculated with freshly thawed pure cultures of Lb. bulgaricus LB-12 and Strep. thermophilus ST-M5, respectively. Inoculated broths of the control and WPI samples were incubated for $5 \mathrm{~h}$ at $43^{\circ} \mathrm{C}$ for $L b$. bulgaricus and $37^{\circ} \mathrm{C}$ for Strep. thermophilus.

Inoculated MRS-THIO containing $0.3 \%$ (wt/vol) oxgall and M17 containing $0.3 \%$ (wt/vol) oxgall broths were serially diluted in $0.1 \%$ (wt/vol) peptone water and pour plated every $\mathrm{h}$ for the $5 \mathrm{~h}$ of incubation. Lactobacillus bulgaricus were enumerated by pour plating using previously prepared MRS agar ( $\mathrm{pH} 5.2$ ) and anaerobically incubated at $43^{\circ} \mathrm{C}$ for $72 \mathrm{~h}$. Streptococcus thermophilus were enumerated by pour plating using previously prepared M17 agar and aerobically incubated at $37^{\circ} \mathrm{C}$ for $24 \mathrm{~h}$ (Dave and Shah, 1998a). After the incubation period, the colonies were counted. Three replications were conducted.

\section{Statistical Analysis}

Data were analyzed separately as a randomized block design with repeated measures for acid tolerance of Strep. thermophilus, acid tolerance of Lb. bulgaricus, bile tolerance of Strep. thermophilus, and bile tolerance of Lb. bulgaricus using Proc Mixed of SAS (version 9.3, SAS Institute Inc., Cary, NC). The WPI concentration and time of exposure were fixed effects, whereas replicates were random effects. Differences of least squares means were used to determine significant differences at $P<0.05$ for main effects (WPI concentration and time of exposure) and the interaction effect (WPI con- centration $\times$ time of exposure). Significant differences $(P<0.05)$ among the main effects were analyzed using Tukey's adjustment.

\section{RESULTS AND DISCUSSION}

\section{Acid Tolerance}

Acid tolerance of Strep. thermophilus ST-M5 as influenced by the addition of WPI over 120 min of incubation is shown in Figure 1. The interaction effect of amount of WPI $\times$ time of acid exposure was significant $(P<$ $0.0001)$. The rate at which the log counts decreased with acid exposure time varied with WPI concentration. For the control, the log count decreased from 9.70 to 5.74 during the first $30 \mathrm{~min}$ of acid exposure but only decreased from 5.74 to 3.89 between 30 and 120 min of acid exposure. The log counts for the 1, 2, and $3 \%$ WPI levels decreased with time of acid exposure at a slower rate than did the control. For the $3 \%$ WPI, the log count only decreased from 10.21 at time 0 to 9.27 at $120 \mathrm{~min}$ of acid exposure.

Although we detected no significant $(P>0.05)$ differences in log counts among any of the WPI levels at time 0 , the log counts at each WPI level were significantly $(P<0.05)$ different from each other at 60,90 , and 120 min of acid exposure, with log counts increasing as the WPI concentration increased. Addition of 1,2 , or $3 \%$ WPI resulted in higher $(P<0.05)$ viable cell counts compared with control samples from 30 to $120 \mathrm{~min}$ of incubation. In addition, the $3 \%$ WPI showed higher $(P$ $<0.05)$ viable cell counts than did 0,1 , and $2 \%$ WPI at $30,60,90$, and $120 \mathrm{~min}$ of incubation. Use of $3 \%$ WPI improved survival of Strep. thermophilus ST-M5 by about $5 \log \mathrm{cfu} / \mathrm{mL}$ compared with control.

Acid tolerance of $L b$. bulgaricus LB-12 as influenced by the addition of WPI over $120 \mathrm{~min}$ incubation is shown in Figure 2. The interaction effect of amount of WPI $\times$ time of acid exposure was significant $(P<0.0001)$. Similar to the acid tolerance for Strep. thermophilus, the rate at which the log counts of $L b$. bulgaricus decreased with acid exposure time varied with WPI concentration. In the control, the log count decreased from 8.44 to 3.99 during the first $30 \mathrm{~min}$ of acid exposure but only decreased from 3.99 to 3.41 between 30 and 120 min of acid exposure. The 1\% WPI treatment followed a similar pattern. We observed a slower decrease in log counts with time of acid exposure for both the 2 and $3 \%$ WPI levels, indicating less death. For 3\% WPI, the $\log$ count only decreased from 8.23 at time 0 to 5.17 at 120 min of acid exposure. Although we detected a $<0.3$ log difference between the counts among various WPI levels at time 0 , the log counts for each WPI level at a given time differed $(P<0.05)$ from each other at 30 , 


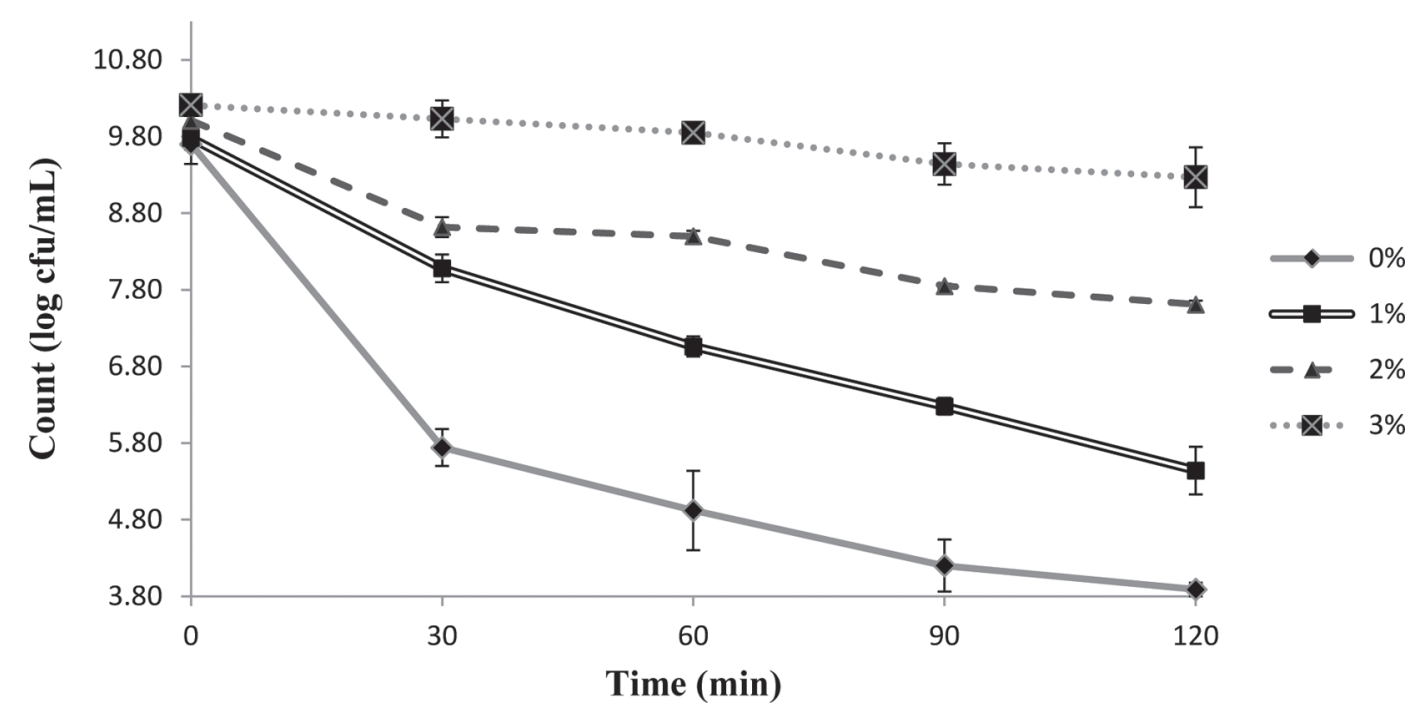

Figure 1. Acid tolerance of Streptococcus thermophilus ST-M5 as influenced by different concentrations $(0,1,2$, or $3 \%)$ of whey protein isolate over an incubation period of $120 \mathrm{~min}$. Error bars represent SE.

60, 90, and $120 \mathrm{~min}$ of acid exposure, with log counts increasing with increasing WPI level. Use of $3 \%$ WPI improved survival of $L b$. bulgaricus LB-12 by about 2 $\log \mathrm{cfu} / \mathrm{mL}$ after exposure to acidic conditions for 30 , 60, 90 and 120 min (Figure 2).

According to Conway et al. (1987), Lb. bulgaricus and Strep. thermophilus are not tolerant to acid environments (i.e., $\mathrm{pH} 3$ ). Lactobacilli strains have higher proteolytic activity and acid tolerance compared with Strep. thermophilus (Shah and Jelen, 1990; Dave and Shah, 1998a,b; Garault et al., 2000). According to
González-Márquez et al. (1997), the optimal pH for growth of lactic acid bacteria is between 5.5 and 7.0, which explains the reduction of viable cells in the control treatment after exposure to acidic conditions for 120 min. According to Nadal et al. (2010), the addition of whey proteins can improve the buffering capacity of a medium, thus reducing the effect of acid environments for the bacterial strain.

According to Lee and Vickers (2008), addition of whey proteins to beverages requires greater amounts of acid to reach a specific acidic $\mathrm{pH}(<4.5)$ compared with

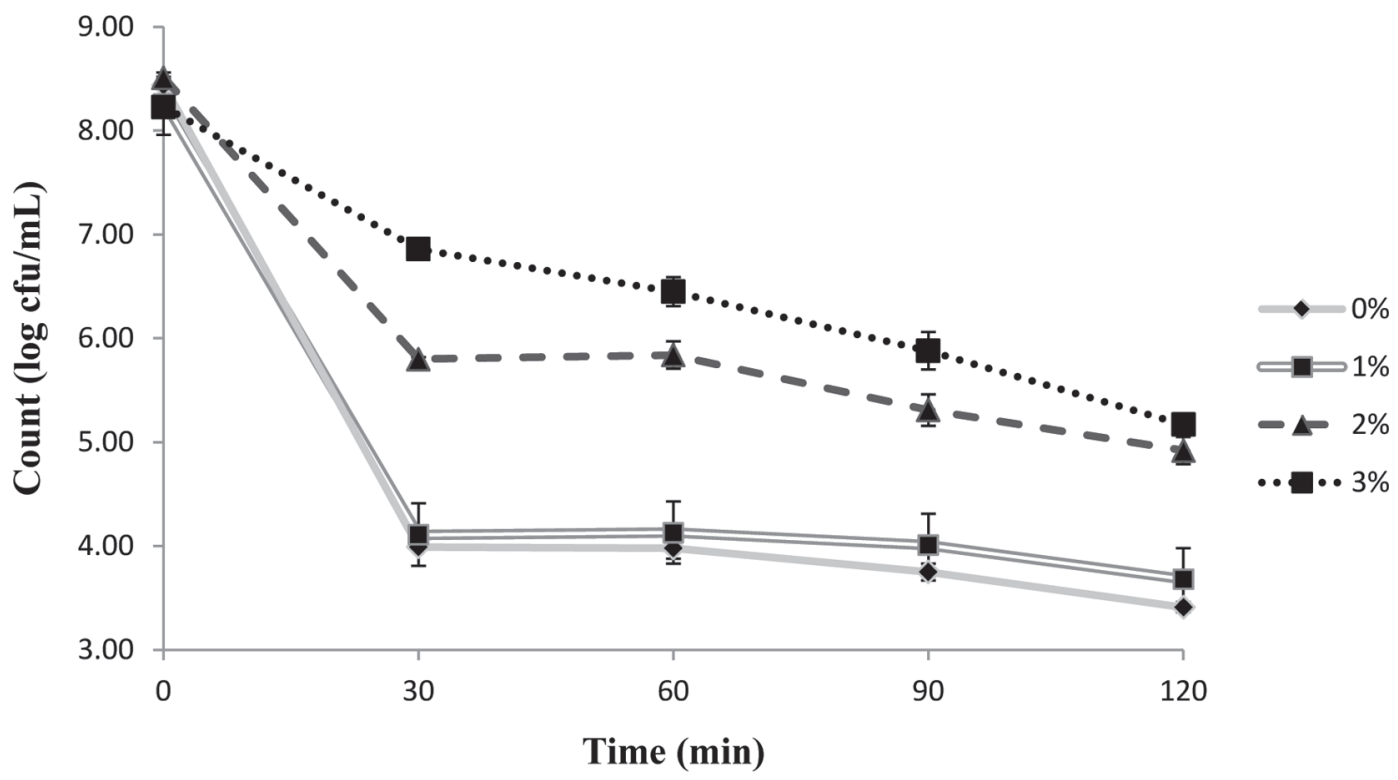

Figure 2. Acid tolerance of Lactobacillus bulgaricus LB-12 as influenced by different concentrations $(0,1,2$, or $3 \%)$ of whey protein isolate over an incubation period of $120 \mathrm{~min}$. Error bars represent SE. 
beverages without whey proteins. Polypeptides are generated from milk proteins by the action of proteinases and peptidases present in cell walls of starter culture bacteria (Salminen et al., 2004). The action of peptidases from cell walls provides peptides and free AA used by starter culture bacteria for metabolic processes (Garault et al., 2000; Salminen et al., 2004; Güler-Akin et al., 2009). The addition of WPI to yogurt mixes increases the amount of protein in the yogurt. Pescuma et al., (2007) evaluated the ability of Strep. thermophilus CRL 804 and Lb. bulgaricus CRL 454 to hydrolyze whey proteins (WPC $89 \%$ protein) in a medium. Streptococcus thermophilus and $L b$. bulgaricus were capable of breaking down up to $21 \%$ of $\beta$-LG and $26 \%$ of $\alpha$-LA into smaller peptides $(7 \mathrm{kDa})$ and free AA (Pescuma et al., 2007). This indicates that the enzymes present in the cell walls of starter culture bacteria have an effect on whey proteins.

An acidic environment kills bacteria by decreasing the cytoplasm $\mathrm{pH}$, affecting internal enzymes, reducing the ability to produce ATP, and making it difficult to produce proteins. Whey protein isolate is a good source of AA needed by bacteria. Amino acid decarboxylases control the $\mathrm{pH}$ of the bacterial environment by consuming hydrogen ions as part of the decarboxylation reaction (Cotter and Hill, 2003). Cotter and Hill (2003) reported that glutamate decarboxylase (GAD), which is present in the gram-positive bacteria Strep. thermophilus and Lb. delbrueckii ssp. bulgaricus, operates by combining an internalized AA (glutamate) with a proton and exchanging the resultant product $\gamma$-aminobutyrate (GABA) for another AA substrate. Thus, an extracellular AA is converted into an extracellular product but the consumption of an intracellular proton results in increase in intracellular $\mathrm{pH}$ (Cotter and Hill, 2003), leading to enhanced acid tolerance by the use of whey proteins.

\section{Bile Tolerance}

Bile tolerance of Strep. thermophilus ST-M5 as influenced by the addition of WPI over $5 \mathrm{~h}$ of incubation is shown in Figure 3. The interaction effect of amount of WPI $\times$ time of bile exposure was significant $(P<$ 0.0001). The change in log counts with bile exposure time varied with WPI concentration. For the control, we detected no significant $(P>0.05)$ differences in log counts after $0,1,2,3$, and $4 \mathrm{~h}$ of bile exposure, but the $\log$ count at $5 \mathrm{~h}$ was significantly $(P<0.05)$ lower than each of the previous log counts. The only significant difference for the 1\% WPI sample was that the 1-h log count was significantly $(P<0.05)$ higher than the 4 -h count. For both the 2 and 3\% WPI samples, the respective $\log$ counts at time 0 were significantly $(P<0.05)$ lower than the log counts for the remaining times $(1,2$, 3,4 , and $5 \mathrm{~h}$ ), indicating bacterial growth. Moreover, addition of 2 or $3 \%$ WPI resulted in higher $(P<0.05)$ viable cell counts than control or $1 \%$ WPI at $2,3,4$, and $5 \mathrm{~h}$ of incubation, indicating beneficial effects of higher concentrations of WPI on bile tolerance of Strep. thermophilus ST-M5.

Bile tolerance of $L b$. bulgaricus LB-12 as influenced by the addition of WPI over $5 \mathrm{~h}$ of incubation is shown in Figure 4. The interaction effect of amount of WPI $\times$ time of bile exposure was significant $(P<0.0001)$. The counts for all WPI levels decreased over time, and the decrease between 2 and $5 \mathrm{~h}$ was greater for the control than for the 1,2, and 3\% WPI levels. Counts at each

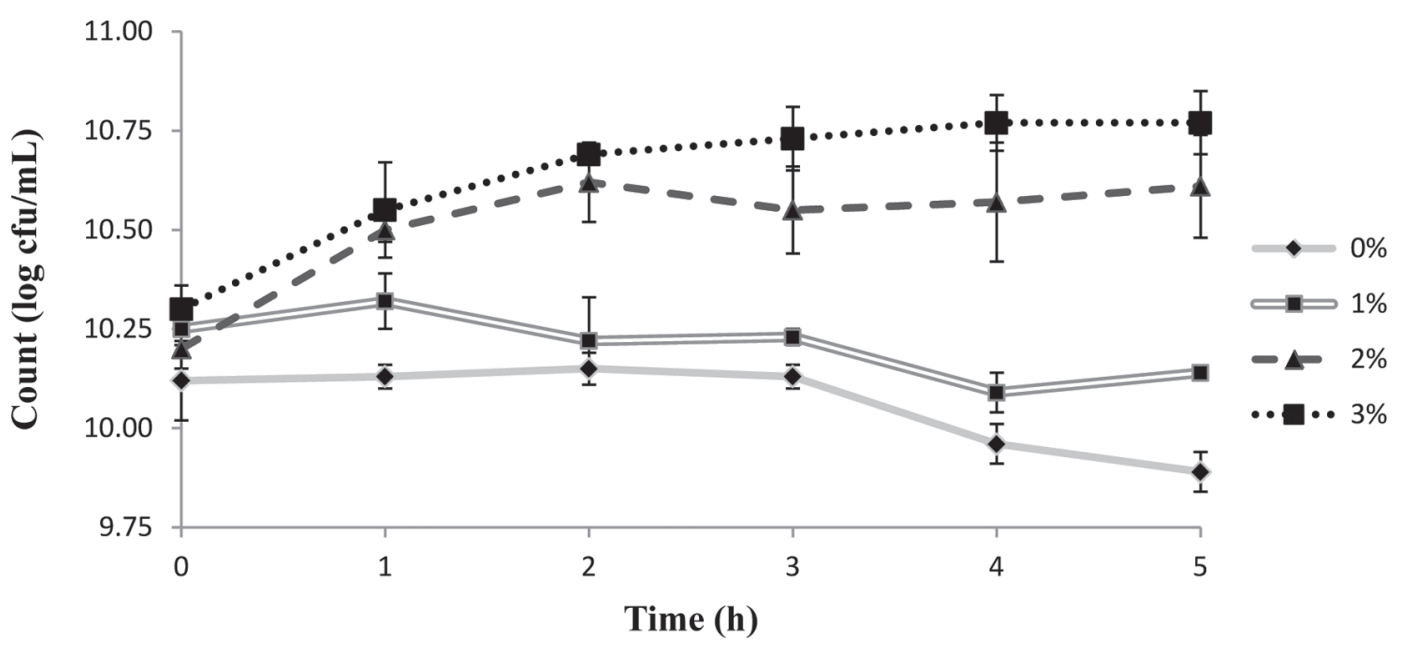

Figure 3. Bile tolerance of Streptococcus thermophilus ST-M5 as influenced by different concentrations (0, 1, 2, or 3\%) of whey protein isolate over an incubation period of $5 \mathrm{~h}$. Error bars represent SE. 


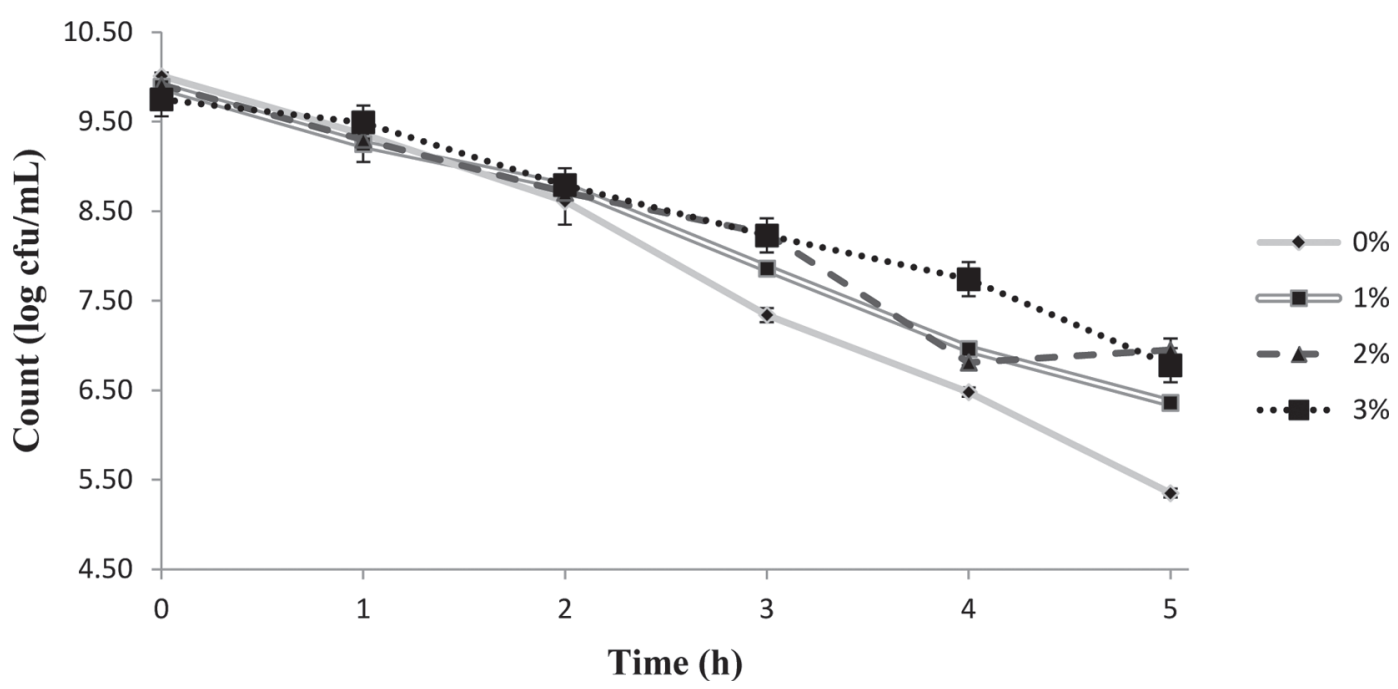

Figure 4. Bile tolerance of Lactobacillus bulgaricus LB-12 as influenced by different concentrations $(0,1,2$, or $3 \%)$ of whey protein isolate over an incubation period of $5 \mathrm{~h}$. Error bars represent SE.

hour were significantly $(P<0.05)$ lower than those at the previous hour for each time for the corresponding WPI level except for the counts at $5 \mathrm{~h}$ for the $2 \% \mathrm{WPI}$ level. At 3,4 , and $5 \mathrm{~h}$ of bile exposure, the counts for the 1,2 , and $3 \%$ WPI were significantly $(P<0.05)$ higher than counts for the control. At $5 \mathrm{~h}$ of incubation, the 2 and $3 \%$ WPI samples showed significantly $(P<$ 0.05 ) higher viable cell counts than the control and $1 \%$ WPI samples. This indicates that the bacterial death was lower for 2 and $3 \%$ WPI compared with 0 and $1 \%$ WPI, confirming the protective effect against cell death from bile when using higher concentrations of WPI.

Bile salts normally affect the survival of bacterial cells because of the high susceptibility of the bacterial cell envelope to bile (Jin et al., 1998). Liong and Shah (2005) reported bile tolerance for strains of $L b$. acidophilus and Lactobacillus casei at $2 \mathrm{~h}$ of incubation in MRS broth containing $0.3 \%$ oxgall. They found the highest cell reduction in MRS broth with $0.3 \%$ oxgall compared with the control (MRS broth). In the current study, the presence of 2 and 3\% WPI increased the survival of $L$ b. bulgaricus LB-12 up to $1.7 \mathrm{log} \mathrm{cfu} / \mathrm{mL}$ at $5 \mathrm{~h}$ of exposure to bile salts compared with control (Figure 4).

According to Charteris et al. (1998), WPI can protect from gastrointestinal stress by acting as a buffering agent and inhibiting activity of digestive enzymes. A decrease in count is normal because of the susceptibility of phospholipid cell walls of bacteria to bile salts (Jin et al., 1998). Bile works as a detergent that emulsifies and solubilizes lipids (Begley et al., 2005). Higher concentrations of bile dissolve lipids present in the phospholipid cell walls of bacteria, making bacteria susceptible to ion-exchange transport, affecting acid adaptation of bacteria and causing shrinkage and leakage of intracellular material and eventually bacterial death (Begley et al., 2005).

Bile salts can cross the cell membrane, damage proteins and DNA, and result in leakage of intracellular material (Gunn, 2000; Begley et al., 2005). Whey proteins may slow down the damage of the bacterial cell proteins or facilitate protein repair. In addition, bile emulsifies fats and the lipid membrane of bacterial cells (Gunn, 2000; Begley et al., 2005). Whey proteins may function as a barrier or a partial barrier between the bile and the lipid membrane of the bacterial cell.

\section{CONCLUSIONS}

Addition of WPI had a positive effect on 2 probiotic properties of yogurt starter bacteria. Use of 1,2 , and $3 \%$ WPI resulted in significantly greater acid tolerance over $120 \mathrm{~min}$ of acid exposure and greater bile tolerance over $5 \mathrm{~h}$ of bile exposure for pure cultures of Strep. thermophilus ST-M5 and Lb. bulgaricus LB-12 compared with controls. Use of $3 \%$ WPI resulted in the highest counts for acid tolerance of Strep. thermophilus ST-M5 and Lb. bulgaricus LB-12. Use of 2 and 3\% WPI resulted in the highest counts for bile tolerance of Strep. thermophilus ST-M5 and Lb. bulgaricus LB-12 over 5 $\mathrm{h}$ of bile exposure. Thus, WPI improved acid and bile tolerance of culture bacteria Strep. thermophilus ST-M5 and Lb. bulgaricus LB-12.

\section{REFERENCES}

Akalin, A. S., S. Gonc, G. Unal, and S. Fenderya. 2007. Effects of fructooligosaccharide and whey protein concentrate on the viability of 
starter culture in reduced-fat probiotic yogurt during storage. J. Food Sci. 72:M222-M227.

Begley, M., C. G. Gahan, and C. Hill. 2005. The interaction between bacteria and bile. FEMS Microbiol. Rev. 29:625-651.

Charteris, W. P., P. M. Kelly, L. Morelli, and J. K. Collins. 1998. Development and application of an in vitro methodology to determine the transit tolerance of potentially probiotic Lactobacillus and Bifidobacterium species in the upper human gastrointestinal tract. J. Appl. Microbiol. 84:759-768.

Conway, P. L., S. L. Gorbach, and B. R. Goldin. 1987. Survival of lactic acid bacteria in the human stomach and adhesion to intestinal cells. J. Dairy Sci. 70:1-12.

Cotter, P. D., and C. Hill. 2003. Surviving the acid test: Responses of gram-positive bacteria to low pH. Microbiol. Mol. Biol. Rev. 67:429-453.

Dave, R. I., and N. P. Shah. 1998a. Effect of cysteine on the viability of yoghurt and probiotic bacteria in yoghurts made with commercial starter cultures. Int. Dairy J. 7:537-545.

Dave, R. I., and N. P. Shah. 1998b. Ingredient supplementation effects on viability of probiotic bacteria in yogurt. J. Dairy Sci. 81:2804-2816.

Garault, P., C. Letort, V. Juillard, and C. Monnet. 2000. Branchedchain amino acid biosynthesis is essential for optimal growth of Streptococcus thermophilus in milk. Appl. Environ. Microbiol. 66:5128-5133.

Garlick, P. J., and I. Grant. 1988. Amino acid infusion increases the sensitivity of muscle protein synthesis in vivo to insulin. Biochem. J. 254:579-584.

Gerez, C. L., G. Font de Valdez, M. L. Gigante, and C. R. Grosso, 2012. Whey protein coating bead improves the survival of the probiotic Lactobacillus rhamnosus CRL 1505 to low pH. Lett. Appl. Microbiol. 54:552-556.

González-Márquez, H., C. Perrin, P. Bracquart, C. Guimont, and G. Linden. 1997. A $16 \mathrm{kDa}$ protein family overexpressed by Streptococcus thermophilus PB18 in acid environments. Microbiology 143:1587-1594.

Güler-Akin, M. B., and M. S. Akin. 2007. Effects of cysteine and different incubation temperatures on the microflora, chemical composition and sensory characteristics of bio-yogurt made from goat's milk. Food Chem. 100:788-793.

Güler-Akin, M. B., M. Serdar Akin, and A. Korkmaz. 2009. Influence of different exopolysaccharide-producing strains on the physicochemical, sensory and syneresis characteristics of reduced-fat stirred yoghurt. Int. J. Dairy Technol. 62:422-430.

Gunn, J. S. 2000. Mechanisms of bacterial resistance and response to bile. Microbes Infect. 2:907-913. (Review).

Jin, L. Z., Y. W. Ho, N. Abdullah, and S. Jalaludin. 1998. Acid and bile tolerance of Lactobacillus isolated from chicken intestine. Lett. Appl. Microbiol. 27:183-185.

Lee, C. A., and Z. M. Vickers. 2008. The astringency of whey protein beverages is caused by their acidity. Int. Dairy J. 18:1153-1156.

Liong, M. T., and N. P. Shah. 2005. Acid and bile tolerance and cholesterol removal ability of Lactobacilli strains. J. Dairy Sci. 88:55-66.
Lucas, A., I. Sodini, C. Monnet, P. Jolivet, and G. Corrieu. 2004. Probiotic cell counts and acidification in fermented milks supplemented with milk protein hydrolysates. Int. Dairy J. 14:47-53.

Marafon, A. P., A. Sumi, D. Granato, M. R. Alcantara, A. Y. Tamime, and M. Nogueira de Oliveira. 2011. Effects of partially replacing skimmed milk powder with dairy ingredients on rheology, sensory profiling, and microstructure of probiotic stirred-type yogurt during cold storage. J. Dairy Sci. 94:5330-5340.

Morifuji, M., J. Koga, K. Kawanaka, and M. Higuchi. 2009. Branchedchain amino acid containing dipeptides, identified from whey protein hydrolysates, stimulate glucose uptake rate in L6 myotubes and isolated skeletal muscles. J. Nutr. Sci. Vitaminol. (Tokyo) $55: 81-86$

Nadal, E. S., E. Sayas-Barberá, J. Fernández-López, and J. A. PérezAlvarez. 2010. Food formulation to increase probiotic bacteria action or population. Pages 335-351 in Bioactive Foods in Promoting Health: Probiotics and Prebiotics. Academic Press/Elsevier, Amsterdam, the Netherlands.

Pedretti, S. 2013. Probiotic market: Up or down? Nutrafoods 12:19.

Pereira, D. I. A., and G. R. Gibson. 2002. Cholesterol assimilation by lactic acid bacteria and bifidobacteria isolated from the human gut. Appl. Environ. Microbiol. 68:4689-4693.

Pescuma, M., E. M. Hebert, F. Mozzi, and G. F. Valdez. 2007. Hydrolysis of whey proteins by Lactobacillus acidophilus, Streptococcus thermophilus and Lactobacillus delbrueckii ssp. bulgaricus grown in a chemically defined medium. J. Appl. Microbiol. 103:1738-1746.

Salminen, S., A. V. Wright, and A. Ouwehand. 2004. Lactic Acid Bacteria: Microbiological and Functional Aspects. 3rd ed. Marcel Dekker, New York, NY.

Shah, N. P., and P. Jelen. 1990. Survival of lactic acid bacteria and their lactases under acidic conditions. J. Food Sci. 55:506-509.

Sowers, S. 2009. A primer on branched-chain amino acids. Literature Education Series on Dietary Supplements:1-6. Huntington College of Health Sciences, Knoxville, TN.

Tharmaraj, N., and N. P. Shah. 2003. Selective enumeration of Lactobacillus delbrueckii ssp. bulgaricus, Streptococcus thermophilus, Lactobacillus acidophilus, bifidobacteria, Lactobacillus casei, Lactobacillus rhamnosus, and propionibacteria. J. Dairy Sci. 86:2288-2296.

Tipton, K. D., T. A. Elliott, M. G. Cree, A. A. Aarsland, A. P. Sanford, and R. R. Wolfe. 2007. Stimulation of net muscle protein synthesis by whey protein ingestion before and after exercise. Am. J. Physiol. Endocrinol. Metab. 292:E71-E76.

Weigle, D. S., P. A. Breen, C. C. Matthys, H. S. Callahan, K. E. Meeuws, V. R. Burden, and J. Q. Purnell. 2005. A high-protein diet induces sustained reductions in appetite, ad libitum caloric intake, and body weight despite compensatory changes in diurnal plasma leptin and ghrelin concentrations. Am. J. Clin. Nutr. 82:41-48.

Wycherley, T. P., M. Noakes, P. M. Clifton, X. Cleanthous, J. B. Keogh, and G. D. Brinkworth. 2010. A high-protein diet with resistance exercise training improves weight loss and body composition in overweight and obese patients with type 2 diabetes. Diabetes Care 33:969-976. 